Article

\title{
Climate Change Impacts in Agricultural Communities in Rural Areas of Coastal Bangladesh: A Tale of Many Stories
}

\section{Nazmul Huq ${ }^{1, *}$, Jean Hugé ${ }^{2}$, Emmanuel Boon ${ }^{3}$ and Animesh K. Gain ${ }^{4}$}

1 Institute for Environment and Human Security (UNU-EHS), United Nations University, Platz der Vereinten Nationen 1, D-53113 Bonn, Germany

2 Systems Ecology \& Resource Management Research Unit, Université Libre de Bruxelles, Avenue Franklin Roosevelt 50, 1050 Brussels, Belgium; E-Mail: jean.huge@ulb.ac.be

3 Department of Public Health, Vrije Universiteit Brussel, Laarbeeklaan 103, B-1090 Brussels, Belgium; E-Mail: eboon@vub.ac.be

4 GFZ German Research Centre for Geosciences, Section 5.4 Hydrology, Telegrafenberg, 14473 Potsdam, Germany; E-Mail: animesh.gain@gfz-potsdam.de

* Author to whom correspondence should be addressed; E-Mail: nazmulhuqrussell@gmail.com; Tel.: +49-228-815-0235; Fax: +49-228-815-0299.

Academic Editor: Marc A. Rosen

Received: 25 March 2015 / Accepted: 19 June 2015 / Published: 30 June 2015

\begin{abstract}
This paper identifies and analyses climate change impacts, their cascading consequences and the livelihood implications of these impacts on smallholder agricultural communities of coastal Bangladesh. Six physically and socio-economically vulnerable communities of south-western coastal regions were studied. Primary data was collected through focus group discussions, a seasonal calendar, and historical transect analysis. Three orders of impacts of climate change on smallholder farmers are identified and described. The first order impacts involve increasing erosion of the capacity of local communities to mitigate vulnerability to climate change impacts. This situation led to the second order impacts, which significantly transformed the agricultural landscape and production patterns. The cumulative effects of the first and second order impacts sparked the third order impacts in the form of worsening community livelihood assets and conditions. The findings of this paper can contribute to the formulation of sustainable adaptation policies and programs to manage the vulnerability of local communities to climate change impacts in the country effectively.
\end{abstract}


Keywords: adaptation; agriculture; Bangladesh; climate change; vulnerability

\section{Introduction}

The frequency and intensity of climatic events such as floods, heat waves, tropical cyclones, and droughts are increasing globally due to climate change [1-3]. Climatic disasters can create long-term positive opportunities such as creating institutional structures for disaster management and improvement in social networking, however, impacts are mostly capable of destroying biodiversity, ecosystem, water resources, and human livelihoods in a cascading order [4]. Examples include the short-term and long-term impacts of the 1991 cyclone in at the Chittagong coast of Bangladesh, causing the deaths of 138,000 people, remarkable reduction of agricultural and industrial production, and millions of displaced people [5,6], and glacier melting in the Himalayas which is changing hydrological flow regime leading to uncertainties of water availability and production to downstream communities $[4,7,8]$. Climatic events also invariably affect the consequent human-environment interactions or socio-ecological systems (SES) and their processes [9] that provide essential social services such as food, fiber, and energy at different levels [10,11]. For example, in 2007 cyclone Sidr in the southwest coast of Bangladesh caused massive destruction to the Sundarbans which is one of the largest mangrove forests in the world. This led to the collapsing of millions of forest-dependent livelihoods and eventually mass emigration of people [12]. Despite the empirical presence; the complex interconnectedness of cascading impacts of climate change impacts are not very evident in the literature. The purpose of this paper is to characterize the cascading impacts of climate change impacts on smallholder agricultural communities in Bangladesh. The characterization of impacts on agricultural communities is thus expected to enable policy-makers to develop appropriate adaptation measures to climate change impacts.

Being one of the most climate-vulnerable countries in the world, Bangladesh is highly susceptible to agricultural damage [13-16]. Small-scale farmers in the developing countries like Bangladesh are most likely to be affected by climate change impacts because of their high dependence on agriculture for sustaining their livelihoods $[13,15,17,18]$. In addition, the population pressure in the country is high; economic development and urbanization are largely unplanned and poverty is endemic $[13,19]$. The multifaceted and combined effects of climate and non-climate related change are manifested by the overall low adaptive capacity of smallholder agricultural communities to withstand climate change impacts [20,21]. Planned climate change adaptation policies and actions are necessary and the Government of Bangladesh (GoB) already prepared national adaptation plan such as the Bangladesh Climate Change Strategy and Action Plan (BCCSAP) of 2009. The fundamental requirement for implementing this action plan is to characterize the impacts because of the fact that adaptation is highly context dependent. Therefore, different communities may require different climate change impacts adaptation plans.

In terms of agriculture, the coastal area of Bangladesh is highly productive. However, the area is most vulnerable to natural hazards than any other part of the country due to the high frequency of hazards and the high exposure of poor local communities to these hazards [22-24]. Coastal flooding 
occurs every year with varied height and intensity. The geographic location of coastal Bangladesh has turned the country into a major hotspot of global tropical cyclone and tidal surges [25,26]. During the last decade, erratic precipitation patterns and an increasing number of cyclones and heat waves have been observed [27-29]. Between 2000 and 2010, the southwestern coastal zone of Bangladesh experienced two mega cyclones which caused enormous economic, infrastructural, agricultural, and human losses [30]. Sea level rise is already observed in coastal Bangladesh [15]. Estimations and projections shows that 97.1 percent of coastal areas and over 35 million people of coastal Bangladesh are vulnerable and exposed to multiple climate change hazards such as tropical cyclones, storm surges, coastal flooding, salinity intrusion associated with global warming and sea level rises [12,29-31].

This area is also ecologically rich because of the combination of coastal mangrove forests, tidal estuaries, productive agricultural lands, and economic activities such as shrimp farming. However, storm surges and coastal flooding are putting serious pressure on agricultural production and are causing reduced productivity [32-34]. Coupled with low socio-economic conditions of the area, the impacts of climatic events like cyclones, storm surges, and tidal flooding eventually negatively affect coastal agricultural communities with regard to their livelihood, income opportunities, education, and food security $[35,36]$. Shrimp farms have recently been constructed in coastal Bangladesh and this is inducing increasing saline water intrusion inland. This is attributed to climatic events such as tidal processes, storm surges, coastal erosion and tropical cyclones [37,38]. Climate change is significantly contributing to increased salinity intrusion in coastal Bangladesh which in turn is destroying biodiversity, loss of agricultural jobs, reduction in agricultural production and mounting food and human insecurity in the area in cascading and consequential orders over different time horizons $[28,30,34,36]$.

The vulnerability of coastal socio-ecological system (SES) is an indication of exposure to climatic stresses, sensitivity to harm, and lack of capacity to cope and adapt $[9,39]$. An important aim of this paper is to provide a comprehensive understanding of the impacts of climate change on agricultural communities in the southwestern coastal region of Bangladesh, a region that is highly susceptible to climate change impacts and socio-economic development pressures [40-42]. Reducing the current vulnerability of agricultural systems is a complex task basically because it is the outcome of a series of complex and systemic interactions of impacts [43-45]. In order to unpack these complexities, it is necessary to identify (i) the different orders of impacts of climate change on small-scale agricultural communities and (ii) how the different orders of impacts are eroding vital community adaptive capacities.

\section{Framing the Different Orders of Climate Change Impacts}

The emergence of anthropogenic climate change has boosted research on climate change impacts and vulnerability. Over the last three decades the understanding of impacts and vulnerability have broadened from technological narrative to a holistic risk reduction approach. Vulnerability can be defined as the degree to which a system is susceptible and exposed to and unable to adapt with the impacts of the climatic stressors $[3,46]$. Vulnerability is understood as a complex phenomenon encompassing both climatic and non-climatic stressors, the socio-economic and cultural contexts, political structure and socio-ecological characteristics [47,48]. O'Brien et al. [42] linked interpretations of vulnerability on the basis of impacts such as outcome vulnerability which indicates linear results of impacts e.g., carbon concentration and contextual vulnerability resulting from 
multidimensional society-climate interactions. Birkmann [41] and colleagues [49] embraced the latter interpretation of vulnerability as a gradually widening concept which is primarily conceptualized as an internal risk factor encompassing physical, social, economic, and environmental factors to cause harm to a system. Impacts are defined as the consequences of interaction of climate change events with the vulnerability of human and natural systems underpinned by other social, physical and environmental variables $[2,3,47,48]$. Similar to the concept of vulnerability, assessment of impacts has been widened from single to multi-dimensional aspects, including non-climatic stimuli such as socio-economic indicators as major determinants of impacts [48,50,51].

One of the important determinants of vulnerability and impacts is "adaptive capacity" which is understood as the ability and capacity of a system to adjust to climate change by moderating vulnerabilities and mitigate impacts [52]. Adaptive capacity refers to the expression of the availability of a series of adaptation options, community capacities to implement these options, and demonstrating community's ability to anticipate, cope and recover from climate change impacts $[47,52,53]$. The concept of adaptive capacity is increasingly used to determine the resilience of SES which is often seen as an opposite phenomenon of vulnerability. The presence of adaptive capacity thus reduces vulnerability through minimizing exposure and susceptibility of the system, consequently reduces impacts and increases the overall system's resilience to climatic events [5,49,54]. Coastal hazards often turn into disasters because of decrease in resilience coupled with low community adaptive capacities and environmental changes [5]. Literature on "sustainable livelihood" emphasizes the presence of social, economic, environmental, physical, and human assets and capitals as adaptive capacity to withstand disaster impacts and to reduce livelihood vulnerabilities [55,56]. The components of "sustainable livelihood" were later adopted as important household and community adaptive capacities for reducing climate change impacts and vulnerabilities [57-59]. Availability of natural capitals (e.g., productive soil and groundwater) is essential for agricultural communities to be able to adapt to extreme climatic events while human and social capital enhance the economic ability to withstand the impacts of extreme climatic events $[55,60,61]$.

The argument is that a vulnerable system produces prolonged impacts on a community's adaptive capacities to climate change. In other words, a system's vulnerability not only halts livelihood development (e.g., social, physical, economic, environmental and human pathways) but also leads to a reversal state of development through a series of spiral orders of impacts. Vulnerability is often contextualized as the end-result of multidimensional interactions of socio-ecological components (e.g., political, institutional, economic, and social structures). Therefore, change in vulnerability leads to multidimensional and interlinked impacts on society and the environment [42]. The interlinks and associated spiral orders of climate change impacts and the relationships amongst climate change, agriculture, and the livelihoods of agricultural communities in southwestern coastal region of Bangladesh are identified and analyzed in the paper.

Not all types of livelihood assets and capitals are simultaneously affected by climatic events like cyclones. In case of successive occurrence of events, impacts are more prolonged and often become tipping points for a new state of SES. Clearly, the impacts of a climatic event are interlinked and tend to produce a cascade phenomenon referred to as orders of impacts. The immediate impacts of a climatic event such as a cyclone on a community's livelihood, assets, and capital can be identified as first order impacts. In the long-term, there are flow-on effects of the first order impacts on land use 
change, migration, long-term food shortage, and decreasing agricultural productivity as was the case of Cyclone Gorki on the Chittagong coast of Bangladesh in 1991, and cyclones Sidr and Aila in Southwest Bangladesh in 2007 and 2009 [12,62-64]. The authors conceptualized the short and long term flow-on effects of the first order impacts and subsequent second and third order impacts. The conceptualization of the different order impacts allows examining complex interconnectedness of difference facades of impacts over different time periods. In other words, the temporal dimension of climate change impacts on a community's adaptive capacities are defined as orders of impacts. The sequencing of the order is as follows: existing vulnerabilities of the system interact with the climatic stressors which initiate the first order impacts [3]. These impacts may be sustained and prolonged in the case of prevailing low adaptive capacities to the second order impacts $[4,12]$. Finally, further disaster events may compel communities to endure a series of tertiary level impacts referred to as third order impacts which eventually tend to increase the system's overall vulnerability $[12,47,50]$. In the case of anticipatory and reactive adaptation, vulnerability could be reduced and impacts could be mediated. However, residual impacts after adaptation may contribute to the subsequent orders of impacts $[47,65,66]$. Figure 1 presents the conceptual framing of the different orders of impacts in relation to climate change drivers, vulnerability and adaptation.

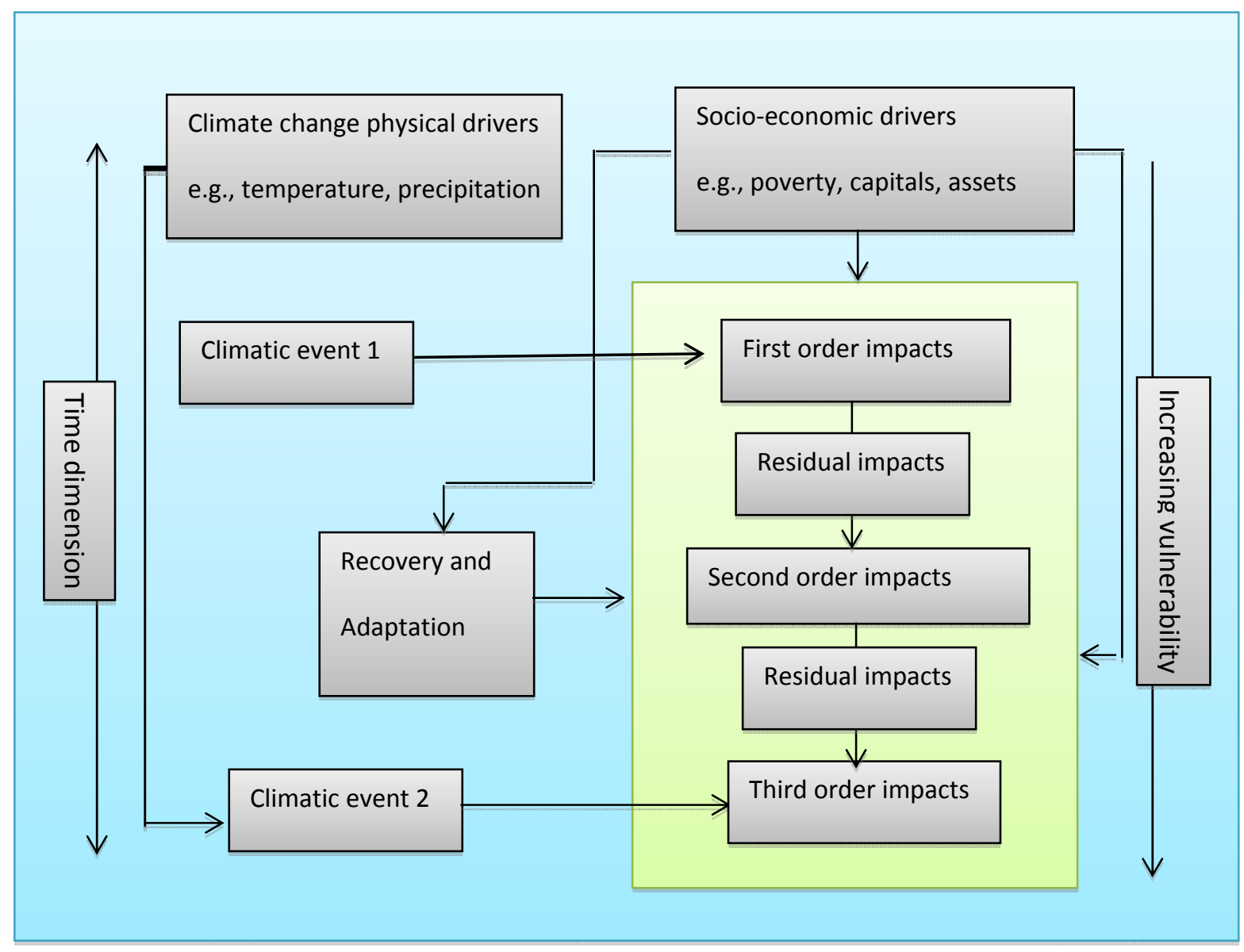

Figure 1. Framing of different orders of impacts.

Although this paper does not analyze existing systems' vulnerability to climate change, its findings can be useful for analyzing such vulnerabilities in future research work that will establish climate change impacts interconnectedness. Clearly, identifying orders of impacts constitutes an important 
component of vulnerability analysis because it can help in defining the level of vulnerability when it is viewed from end point of a consequence [42]. Addressing vulnerability on a long-term basis is the best approach to developing the resilience of local communities against natural hazards [67]. On the other hand, the framework should not universally be conceived as a diagnostic tool for determining climate change impact because of the contextual nature of impacts, vulnerability, and adaptation. At the same time, the paper does not consider the positive window of opportunity created by climate change impacts such as creation of new institutions, stronger social networks, and other positive transformations in its analytical framework.

\section{Materials and Methods}

Information on climate change impacts on agricultural communities in the southwestern coastal region of Bangladesh was collected from members of six communities through a participatory approach. A "micro level" case study approach was used. As advised by Moser and Stein [68], a participatory approach was adopted in the field investigation to provide insights into the experience of the impacts of extreme weather events among low-income groups in a way that macro-level analysis cannot do. The Participatory Rural Appraisal (PRA) as "an approach and a range of methods for learning about rural life and conditions from, with and by rural people" [69] method was used. PRA provides comparative advantages over conventional questionnaire-based studies as it enables "people to express, enhance, share and analyze their knowledge" [68] and its different tools such as transect, livelihood analysis, in-depth interview, Focus Group Discussion (FGD), seasonal analysis, trend analysis, and resource mapping is extensively used for analyzing vulnerability of rural communities $[69,70]$. This research mostly used FGD, risk and resource mapping (RRM), vulnerability assessment (VA), and timeline analysis tools for primary data collection. The selection of data collection tools were influenced by the earlier environmental and land use vulnerability studies in the same region e.g., Hasan and Roe [71] who used wide range of PRA tools.

The field studies were conducted between 2009 and 2011. In July 2009, a weeklong field-testing of the methods in a village called "Shiali" revealed that three methods such as (i) semi-structured FGD; (ii) seasonal calendar; and (iii) historical transect were able to generate comprehensive community views and information for analysis. VA and RRM were extensively used as part of the FGD process to collect information on local resources, resource vulnerability, and vulnerability orders, which were not always possible to realize through the use of other research methods. Table 1 presents the different methods used during the field investigations.

Group discussions (15-20 participants) were held in each of the six agricultural communities. Discussions started with a brief presentation explaining the research purpose and the expectations from the group to identify their vulnerability to climate change considering communities' resources, capacities, environmental changes, degradation, and evidences of extreme climate events. The groups were asked to identify their social, economic, natural, human, and physical vulnerabilities to extreme climatic events. In a subsequent stage, the groups were asked to rank the vulnerabilities according to their order of occurrence. Participants also drew connections between different impacts on different orders of occurrence and this showed how the different orders interacted with each other. Finally, the different orders were clustered as first, second, and third order vulnerabilities of climate change impacts. 
Table 1. Methods used in the PRA process.

\begin{tabular}{|c|c|c|}
\hline Name of the Methods & Techniques Used & Purpose: to Generate Information on \\
\hline \multirow{3}{*}{ FGD } & Semi structured discussions & $\begin{array}{l}\text { - Risk, livelihood, climate change } \\
\text { impacts, major disaster impacts }\end{array}$ \\
\hline & $\begin{array}{l}\text { Vulnerability Analysis } \\
\text { (Discussion) }\end{array}$ & $\begin{array}{l}\text { - Agricultural vulnerability } \\
\text { - Livelihood vulnerability } \\
\text { - Interconnection on vulnerability } \\
\text { - Vulnerability ranking }\end{array}$ \\
\hline & $\begin{array}{l}\text { Risk and resource mapping } \\
\text { (discussion and drawing) }\end{array}$ & $\begin{array}{l}\text { - } \text { Major resources } \\
\text { - } \text { Major risks } \\
\text { - Resource vulnerabilities } \\
\text { - Risk ranking } \\
\end{array}$ \\
\hline Seasonal calendar & Drawing and discussion & - Changes of agricultural production \\
\hline Historical transect & Drawing and discussion & $\begin{array}{l}\text { - Future outlook, evolution of } \\
\text { vulnerability and risks. }\end{array}$ \\
\hline
\end{tabular}

The authors also used risk and resource mapping (RRM) to collect information on land, water, crops and other local resources (resource mapping) and on climatic risks on significant local resources (risk mapping) [70,72]. RRM was carried out with the same group of participants. The groups were asked to produce their community (village) maps showing major resources. In combination with other tools such as the seasonal calendar (trend of agricultural production in different seasons of the year) and historical transect (timeline of the key disaster events), the RRM exercises were done in a retrospective manner and coincided with the historical transect analysis, which also depicted the changes of resources e.g., increase or decrease that occurred over time. The process also made it possible to simulate future changes taking into account the current social, economic and environmental factors. The results of the process were plotted from 1990 to the survey year 2010/11 and projected to the year 2020. Another PRA method called a pie diagram was used to draw the communities' quantitative perceptions on different issues. This method involves a graphical presentation of data and information to allow comparison of sizes, amounts, quantities, and proportions. It is mostly used to help the local people to arrive at quantitative conclusions [70]. It was used as a complementary research tool to facilitate discussions on special issues like food security.

\section{Study Location}

As has already been mentioned, the paper focuses on six southwestern coastal communities of Bangladesh. Six villages of southwest Khulna District were selected as the study location because they are very representative of coastal agricultural communities. The area is characterized by a rapidly growing population 70 percent of which is directly dependent on small-scale agriculture. The communities belong to the same administrative zone (Union; a small local government sub-division) situated in the Low Elevation Coastal Zone (LECZ) of the country. LECZ could be defined as of areas with a coastline up to a 10-meter sea level elevation [73]. The names of the communities are: (a) Pithaboag; (b) GoalbarirChar; (c) Doba; (d) Goara; (e) Putimari; and (f) Dhopokhola. Coastal areas of Bangladesh manifest different climatic and non-climatic vulnerabilities such as tropical cyclones, 
salinity intrusion, and endemic poverty. As part of the coastal region, the communities also endure frequent climatic disasters such as the tropical cyclones of 2007 and 2009 and flooding. Figure 2 shows the location of the study area in context of Bangladesh.

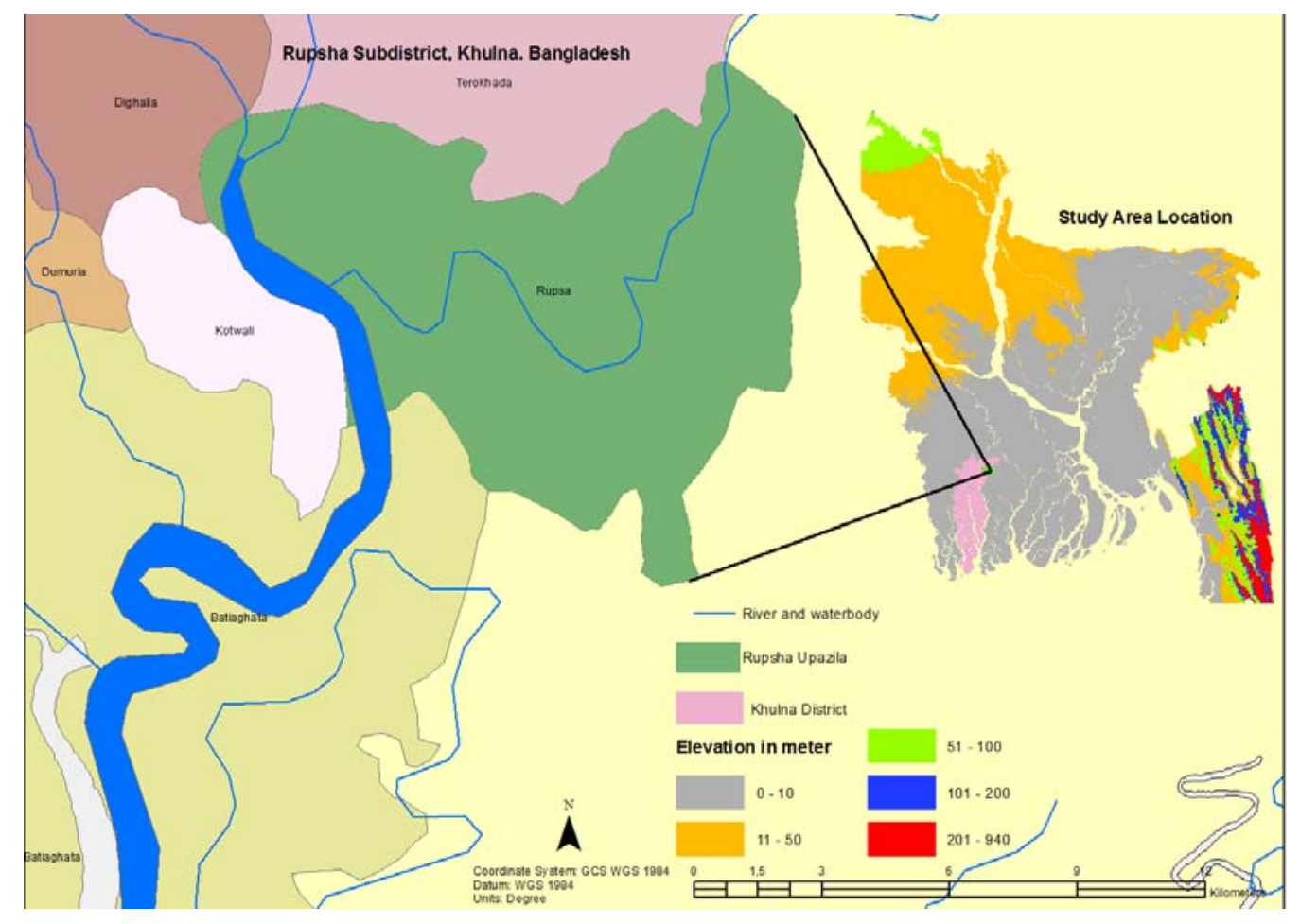

Figure 2. Location of the study area.

\section{Results and Discussions}

\subsection{First Order Impacts}

The research primarily centered on the major impacts of climate change on the livelihoods of the agriculture-dependent communities in the study area. The research first identified the general pattern of natural disasters and vulnerabilities as entry points for identifying the different levels of impacts on the surveyed communities. In addition to natural disasters like cyclones and tidal surges in the study area, the research identified increasing vulnerabilities induced by human activities such as salinity intrusion which is mainly caused by the expansion of shrimp farming. An important observation of the research is that extreme climatic events are on the rise in the coastal region of Bangladesh and are inevitably increasing livelihood stresses in the area. The trend of significantly damaging climatic events in the study location between 1987 and 2009 is depicted in Table 2. 
Table 2. Major natural disaster events and impacts in the study location between 1987 and 2009 .

\begin{tabular}{|c|c|c|c|}
\hline Year & Disaster & National Impacts & Immediate Local Impacts \\
\hline 1987 & Flood & $\begin{array}{l}40 \% \text { area affected, } \\
2055 \text { killed, } \$ 727,500,000 \\
\text { economic loss }\end{array}$ & Loss of rice production \\
\hline 1988 & Flood, Cyclone & $\begin{array}{l}63 \% \text { area affected, } \\
2137 \text { killed, } \$ 2,137,000,000 \\
\text { economic loss }\end{array}$ & $\begin{array}{l}\text { Agricultural loss (mostly "Boro }{ }^{1 "} \text { and } \\
\text { seasonal vegetables), Human casualties } \\
\text { ( } 5708 \text { people in whole cyclonic region), } \\
\text { Loss of shelter, Long term food shortage }\end{array}$ \\
\hline 1991 & Cyclone & $\begin{array}{l}138,000 \text { killed, } \\
\$ 1,780,000,000 \text { economic loss }\end{array}$ & $\begin{array}{l}\text { Complete damage of "Boro" production, } \\
\text { Loss of shelter }\end{array}$ \\
\hline 1994 & Cyclone & $\begin{array}{l}400 \text { people killed, economic } \\
\text { damage data not available }\end{array}$ & Agricultural and shelter loss \\
\hline 1995 & Cyclone & $\begin{array}{l}650 \text { people killed, economic } \\
\text { damage data not available }\end{array}$ & Agricultural and shelter loss \\
\hline 1997 & Cyclone & $\begin{array}{l}126 \text { killed, economic damage } \\
\text { data not available }\end{array}$ & Agricultural loss \\
\hline 2000 & Flood & $24 \%$ area affected & $\begin{array}{l}\text { Loss of rice production, Loss of shrimp } \\
\text { production, Aquaculture loss, Water logging, } \\
\text { Intrusion of saline water }\end{array}$ \\
\hline 2002 & $\begin{array}{l}\text { Flood, High tide, } \\
\text { Heat wave }\end{array}$ & $10 \%$ area affected & $\begin{array}{l}\text { Agricultural loss, Loss of shrimp production, } \\
\text { Loss of shelter }\end{array}$ \\
\hline 2004 & Flood & $37 \%$ area affected & $\begin{array}{l}\text { Loss of agriculture, shrimp and shelter, } \\
\text { Salinity intrusion, Water logging }\end{array}$ \\
\hline 2005 & $\begin{array}{c}\text { Cyclone, Cold } \\
\text { wave }\end{array}$ & Data not available & Shelter loss, Loss of standing crops \\
\hline 2006 & $\begin{array}{c}\text { Cyclone, Tidal } \\
\text { surge, Flood } \\
\end{array}$ & Data not available & $\begin{array}{l}\text { Agricultural damage, Salinity intrusion, } \\
\text { Short term food shortage }\end{array}$ \\
\hline 2007 & $\begin{array}{l}\text { Flood (2 times), } \\
\text { Water logging, } \\
\text { Cyclone }\end{array}$ & $\begin{array}{l}50 \% \text { area affected by flood, } \\
1230 \text { killed, } \$ 114,000,000 \\
\text { economic damage } \\
4275 \text { killed by cyclone, } \\
\$ 2,300,000,000 \text { economic loss }\end{array}$ & $\begin{array}{l}\text { Human casualty, Loss of infrastructure, Loss } \\
\text { of shelter ( } 80 \% \text { of the houses), Loss of both } \\
\text { "aman }{ }^{2 \%} \text { and "boro" (nearly } 100 \% \text { of the } \\
\text { crops), Loss of shrimp and aquaculture } \\
\text { (nearly } 100 \% \text { ), Long term food insecurity, } \\
\text { Loss of livelihood security e.g., income and } \\
\text { employment }\end{array}$ \\
\hline 2008 & $\begin{array}{l}\text { Cyclone, Flood, } \\
\text { Heat wave, Tidal } \\
\text { surge }\end{array}$ & $\begin{array}{l}55 \text { killed, economic damage } \\
\text { unknown }\end{array}$ & Loss of standing crop, Salinity intrusion \\
\hline 2009 & Cyclone & $\begin{array}{l}197 \text { killed, } \$ 270,000 \\
\text { economic loss }\end{array}$ & $\begin{array}{l}\text { Loss of shelter ( } 50 \% \text { of the houses), Salinity } \\
\text { intrusion, Loss of standing crop (nearly } 80 \% \\
\text { of the total crop), Food shortage }\end{array}$ \\
\hline
\end{tabular}

1 "Boro" is a type of rice cultivated during December-May under irrigated condition; ${ }^{2}$ "Aman" is type of rice cultivated during July-December. Source: $[6,74]$ and own field survey data.

From the communities' perspectives, two important issues emerged from Table 2. Firstly, the surveyed communities suffered from all the major disasters that Bangladesh experienced during the 
last 25 years. Table 3 also indicates that the nature of seasonal climatic characteristics have gradually intensified which seriously affect the adaptive capacities of the communities. Secondly, the number of climate change events is on the increase and therefore leaves very little time for the communities to develop adequate adaptation measures to mitigate the impacts. Consequently, recovery processes are unable to restore the pre-event state of livelihood assets and capitals. More importantly, intensification of climatic events increases the proportion of residual impacts which put further stresses on a community's livelihood and causes further flow-on impacts in a cascading manner. One villager responded during a FGD session:

"How can we survive should the flooding (cyclone and tidal surges together) is too frequent? Our life was dismantled after the 2007 Sidr cyclone and we faced two more in 2009. We need to leave."

This response summarized the cumulative vulnerabilities that initiated a range of adverse impacts on their lives and livelihoods. Small-scale agricultural practices in the study location are facing mounting pressures because of the increasing number of extreme climatic events. The increasing number and magnitude of natural disasters is impacting all aspects of community resources and capacities, including water pollution and destruction of biodiversity as first order impacts. In this connection, the authors analyzed the impacts of two successive tropical cyclones that hit the coastal areas in 2007 and 2009. In-depth FGDs and VA conducted in the surveyed communities indicated that Cyclone Sidr of 2007 contributed significantly to decrease core community livelihood capacities in different degrees (see Table 3).

Table 3 shows that just after Cyclone Sidr, many of their core livelihood capacities suffered negatively which showed a recovery pathway year after the cyclone. Aided by the assistance of the Government and NGO interventions, the communities were in the road to bouncing back after a year. Cyclone Aila hit after more than a year in 2009 and significantly affected the livelihood capacities of the communities which were just underway to recovery from the impact of Cyclone Sidr. The impacts of Cyclone Aila consequently degraded the adaptation capacities of the communities below the pre-Sidr level. The physical and natural capacities such as land use, water, vegetation, and soil which are considered as essential livelihood components were seriously eroded. The communities feared that these kinds of extreme climate change events could be more frequent in the coming years. This critical local perception on the frequency of natural disasters in the future is completely in line with scientific findings of increasing cyclonic disasters in the Bay of Bengal region [2,3,75]. The bottom-line of the first order impact is to aggravate the existing vulnerability of the communities since they could not recover properly. This resulted in prolonged sufferings termed as "second order impacts". 
Table 3. Capacities of community to adapt impacts of natural disasters.

\begin{tabular}{|c|c|c|c|c|}
\hline $\begin{array}{c}\text { Community Asset } \\
\text { Dimensions }\end{array}$ & $\begin{array}{c}\text { Components of } \\
\text { Capacities }\end{array}$ & $\begin{array}{l}\text { State after Cyclone } \\
\text { Sidrin } 2007\end{array}$ & $\begin{array}{l}\text { State after } 1 \text { year } \\
\text { of Sidr } 2008\end{array}$ & Explanation \\
\hline 1. Physical & Land use & Decreasing $(-)$ & Decreasing $(-)$ & $\begin{array}{l}\text { Rice to shrimp farm conversion } \\
\text { occurs steadily. }\end{array}$ \\
\hline \multirow{4}{*}{ 2. Social } & Education & No changes & Increasing $(+)$ & No apparent impacts \\
\hline & $\begin{array}{l}\text { Government } \\
\text { supports }\end{array}$ & Increasing $(+)$ & Increasing $(+)$ & $\begin{array}{l}\text { Government support increases } \\
\text { steadily through safety net } \\
\text { programmes. }\end{array}$ \\
\hline & Loan & Decreasing $(--)$ & Increasing $(++)$ & $\begin{array}{l}\text { Cash loan flow reduced after } \\
\text { climatic events because everybody } \\
\text { needs money. }\end{array}$ \\
\hline & Peer support & Increasing $(++)$ & Increasing $(+)$ & $\begin{array}{l}\text { Peer support other than cash loan } \\
\text { increases after a climatic shock. }\end{array}$ \\
\hline \multirow{5}{*}{ 3. Economic } & Shrimp farming & Increasing $(+)$ & Increasing $(+)$ & $\begin{array}{l}\text { Saline water intrusion encourages } \\
\text { shrimp farming. }\end{array}$ \\
\hline & Rice farming & Decreasing $(-)$ & Increasing $(+)$ & $\begin{array}{l}\text { Saline water intrusion reduces rice } \\
\text { farming. }\end{array}$ \\
\hline & $\begin{array}{c}\text { Home stead } \\
\text { gardening }\end{array}$ & Decreasing $(-)$ & Increasing $(++)$ & $\begin{array}{l}\text { Soil and water salinity prevents } \\
\text { homestead agriculture. }\end{array}$ \\
\hline & Microcredit & Increasing $(++)$ & Increasing $(+)$ & $\begin{array}{l}\text { Lack of cash loan from peer groups } \\
\text { increases microcredit flow. }\end{array}$ \\
\hline & Income & Decreasing $(-)$ & Increasing $(+)$ & $\begin{array}{l}\text { Agriculture, fish pond, and rice } \\
\text { fields destroyed. }\end{array}$ \\
\hline \multirow{3}{*}{ 4. Environmental } & $\begin{array}{c}\text { Natural } \\
\text { vegetation }\end{array}$ & Decreasing $(-)$ & Increasing $(+)$ & $\begin{array}{l}\text { Natural vegetation degraded after a } \\
\text { climatic event. }\end{array}$ \\
\hline & $\begin{array}{l}\text { Rivers, canals } \\
\text { and pond }\end{array}$ & Decreasing $(-)$ & Decreasing $(-)$ & $\begin{array}{l}\text { Even one year after a climatic } \\
\text { event, rivers and ponds were } \\
\text { increasingly silted and salinized. }\end{array}$ \\
\hline & Soil & Decreasing $(--)$ & Decreasing $(-)$ & Soil salinity increases. \\
\hline \multirow[b]{2}{*}{ 5. Infrastructural } & Roads & Decreasing $(-)$ & Increasing $(+)$ & Road conditions gradually improve. \\
\hline & $\begin{array}{l}\text { Market and } \\
\text { market access }\end{array}$ & Decreasing $(-)$ & Increasing $(+)$ & Local market access improves \\
\hline
\end{tabular}

Source: Field Survey Data, 2009, 2011; (scale: +/- small increase/decrease, $++/--$ significant increase/decrease).

\subsection{Second Order Impacts}

The second order of climate change impacts were influenced and triggered by the residuals of the first order impacts and assisted by existing low socio-economic status. Fewer livelihood resources withstand the recovery process and lead to persistent and prolonged impacts in many cases. The results of intensive discussions with members of the surveyed communities indicated that many adaptation capacities were showing signs of significant erosion one year after Cyclones Sidr and Aila. While many of these capacities were showing signs of improvement, a few of them like land use changes, water quality, soil salinity, other physical assets, and social support systems were significantly degraded because of two main reasons. Firstly, the strong magnitude of climatic events severely flooded 
agricultural land with saline water. Clearly, the land could not be easily re-used for agricultural purposes. Consequently, the communities were often forced to shift from rice farming to shrimp cultivation and this in turn increased the future vulnerability of the coastal communities. Secondly, the communities regarded this shift as a forced adaptation. They stressed that if there had been no major disaster event they could have resumed normal agricultural production within two seasons.

Cyclone Aila in 2009 buried the prospects of the communities' capacity to recover from the impacts of Cyclone Sidr in 2007. The impacts of Aila essentially initiated another first order impact, slowed down and interrupted the whole recovery process and turned the pre-existing temporary salinity problem into a permanent one. Thus, the frequencies and magnitude of events triggered and turned the first order impacts to second order impacts. The members of the communities were reluctantly leaning towards shrimp farming not because of high profitability but due to the continuous salinization of agricultural lands and ponds. For example, during the devastating Cyclones Sidr (2007) and Aila (2009), seawater entered and submerged agricultural fields, fresh water fishponds and homestead agricultural fields. As a result, many farmers in the whole south west coastal region, including the study area, could not continue normal farming practices because of non-availability of freshwater and irrigation facilities [76]. These disasters forced many community members to move to saline water shrimp farming (Bagda). Saline water shrimp farming is relatively economically more profitable than freshwater shrimp cultivation (Galda). However, traditional small-scale farmers barely participate in shrimp cultivation because of the high capital and inputs costs, frequent viral infections, and the need for large ponds or fields (Own survey, 2010). Therefore, intensified natural disaster events converted temporary impacts into long lasting impacts; e.g., from temporary salinity to permanent salinity. Historical transect analysis of the members of the surveyed communities revealed that saline water shrimp farming exceeded the total area under rice cultivation between 1990 and 2010 and is projected to cover more than three quarters of agricultural land by 2020. However, the introduction of mechanized technologies, insecticides, fertilizers and hybrid rice species, allowed the monetary value of agricultural production to double between 2000 and 2009 compared to the previous decade. But at the same time, the incidence of poverty also increased because small farmers cannot continue farming like commercial shrimp farmers.

\subsection{Third Order Impacts}

Third order impacts heavily affected the communities and lasted the longest time. Members of the surveyed communities argued that in most cases first and second order impacts are (quasi) effects felt right after the disaster events. Third order impacts often manifested as the cumulative and lasting form of vulnerabilities of the whole livelihood system and which gradually erode the vital adaptation capacities of the communities. The two consecutive cyclonic events in 2007 and 2009 led to the further deterioration of adaptive capacities and livelihood sources of the communities.

\subsubsection{Food Security}

Nearly $2 / 3$ of the respondents suffered from food insecurity and limited access to food markets. The impacts of natural disasters extended the period of food insecurity and sometimes prevailed throughout 
the year. Although food insecurity has historically been an issue in the communities, in a space of three decades the situation became bleaker.

Pie diagram exercises were conducted in tandem with FGD sessions to identify the underlying causes of food insecurity as well as their relative contribution to weakening the adaptive capacities of the communities. Figure 3 indicates that food insecurity was not only caused by the impacts of climatic events, but also a number of socio-ecological and economic factors worsened the already dire food security situation. Other causes included increasing poverty and high prices of basic food commodities which put pressure on the agriculture dependent communities (Figure 3).

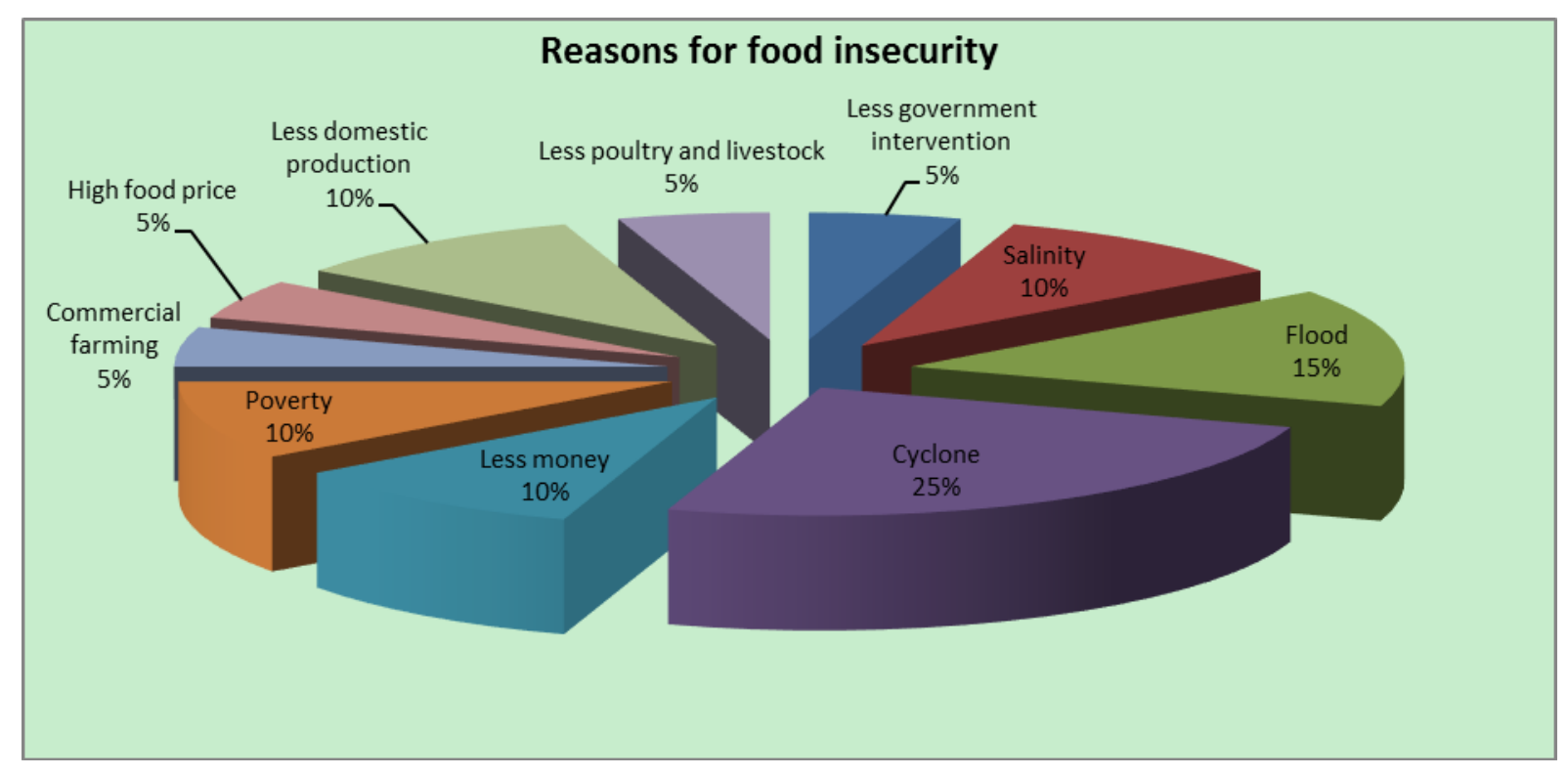

Figure 3. Causes of food insecurity. (Source: reproduced from own survey data 2009, 2011).

\subsubsection{Economic Security}

By destroying most of their resources such as agricultural crops, fisheries, infrastructure and homes, climate change impacts have a direct effect on the income of the surveyed communities. To a very large extent, the introduction of shrimp cultivation has increased income polarization in the communities. Smallholder farmers are not adequately equipped to cultivate shrimps and are therefore forced to lease their land to rich farmers. Consequently, the income gap is widening and influencing the incidence of poverty and food insecurity (Figure 3). In the long-term, financial security of the farmers is in jeopardy since government support is inadequate and is not provided in a timely manner. Members of the communities had very low savings and resources; it therefore took between six months and three years to recover from the impact of natural disasters. In the case of successive or multiple natural disasters, all the interviewees indicated it would be impossible to bounce back at all. This finding of the paper is supported by the results of the similar studies on Bangladesh's coastal communities [77]. Low income often hindered the population of these communities to have access to livelihood assets which in turn increased their vulnerability and led to a chronic aggravation of their financial and economic security. 


\subsubsection{Health Security}

The community members interviewed indicated that their health status was at stake during and after natural disasters such as cyclones. While more than two hundred families were reportedly severely affected in the Ghatbogh Union during Cyclones Sidr and Aila, long-term impacts such as skin diseases and malnutrition were common among all the shrimp farmers. Exposure to saline water and less calorie intakes were the main causes of the diseases (Own Survey 2010). Different groups of respondents (Table 4) identified different causes of persistent nutrition insecurity, which contributed to a decline in the overall health status of the area. Different groups identified the same variables in different order. However, the majority of the causes are connected with increasing salinity (production and income losses). Risk mapping and VA conducted in the communities indicated that lack of access to safe drinking water was a common problem and was aggravated because of the saline water intrusion caused by shrimp farming, high tides, and cyclones. In addition, most community members do not have access to medical treatment due to their weak economic situation, poor communication system, inadequate medical facilities, and remoteness from the district hospital.

Table 4. Major reasons for nutrition insecurity in the study area.

\begin{tabular}{clll}
\hline No & Mixed Group & Women Group & Key Informants \\
\hline 1 & Increased poverty & Decrease in variety of agricultural products & Increased poverty \\
2 & Inadequate awareness lacking & Salinity & Decrease in variety of agricultural products \\
3 & Low income & Low income & Decline in homestead gardening \\
4 & Salinity & Inadequate food stocks & Low income \\
5 & Fall in agricultural production & Decline in homestead gardening & Inadequate awareness \\
\hline
\end{tabular}

Source: Own survey data 2009, 2010.

\subsubsection{Environment and Ecological Security}

The threat to the ecosystem of the study location was found to be on the increase. However, issues related to the natural environment and ecosystem were not the most important concern of the communities. They however exhibited a significant level of awareness of the long-term impacts of rapidly increasing salinity intrusion in the area. This is considered to be the main cause of declining soil fertility, reduction of traditional homestead gardening, declining variety of local foods, shortage of quality drinking water sources and the spread of skin diseases. The respondents also identified the link between increasing salinity and the rise in poverty levels. Smallholder farmers were forced to give up their traditional rice cultivation and adopt shrimp farming which is not affordable for most of the farmers because of high cost of capital inputs. Climate change impacts have immediate and long-term ecological consequences. For example, stagnation of saline water forced members of the communities to change their land use practices permanently. It also destroyed small-scale homestead aquaculture and damaged homestead ecosystem and biodiversity. Similar studies (e.g., Rabbani et al. [76,78]) on coastal settings found devastating impacts on coastal vegetation and ecosystems in Satkhira district. In addtion, Vineis et al. [79] reported increased salinity in the dry season which contributed to increased groundwater salinity, soil degradation, and a lower yield and acreage of rice while Ali [80] observed 
that shrimp farming in coastal regions affected village ecosystem by reducing soil fertility, changes in soil properties and disrupting rice-fish aquatic ecosystems.

\subsubsection{Social Network Security}

Existing social networks and support such as social relationships, social bond, and formal support from local government. Micro-credit organizations considerably helped the communities to improve their adaptive capacities and resilience after the natural disasters. Frequent disasters such as cyclones and the slow onset impacts like land use changes and increasing salinity significantly affected livelihoods in the surveyed communities. Local government institutions were too dysfunctional and were therefore unable to offer any long-term support to the communities. Inaction from formal institutions increased the pressure on informal social networks. However, the communities indicated that informal local networks were not very effective in the face of successive large-scale disasters such as the 2007 and 2009 cyclones. The impacts of the cyclones on the community resources put pressure on cooperatives and NGOs to provide the community members with loans to help them to recover. As Table 3 illustrates, peer support in the form of voluntary labor contribution, interest-free loans and access to peer food banks at times of emergency became increasingly inaccessible.

Figure 4 illustrates the results of the discussions on climate change impacts relating to the third order vulnerabilities. The results were obtained using a "scoring method" where participants were asked to assign values to their livelihood indicators on scale of 1 (very low) to 10 (very good). The combined results showed that a typical area of southwest coastal Bangladesh is not very capable of protecting its livelihood from climatic stresses. For example, food, health and ecological security were under severe pressure. Without external assistance to mitigate salinity, provision of credit and irrigation facilities, members of the communities anticipated further degradation of the situation. Economic security is volatile but somewhat better. However, shrimp farming mainly produced benefits for relatively rich local farmers and absentee commercial farmers. This activity hardly provided any benefits for the local people and the economy. With regard to the first and second orders of vulnerability, some of the livelihood assets in the communities were recovering positively. However, in the case of frequent disasters the livelihood assets suffered a major deterioration.

The findings of this paper are consistent with those of other research work on health, ecological, economic, and social network impacts in coastal settings in Bangladesh [26,76,79,81,82]. The present paper identified the consequential occurrence of different orders of impacts on six surveyed agricultural communities. These communities were able to recover well from the first and second orders of vulnerability. The time difference between two cyclones in 2007 and 2009 suggest that residual impacts of the first cyclone were exacerbated by the additional impacts of the second cyclone. The accumulated impacts of the two disasters rendered mitigation measures very ineffective to a large extent. In other words, these impacts resulted huge consequences on agricultural production and the economy. Diseases and health problems increased the strain on the already stressed populations suffering from vulnerable financial and economic conditions. Most smallholder farmers spent their savings and assets such as jewelry and livestock. Many of them also took loans from NGOs, cooperatives, and rich local people and this put them under enormous economic insecurity. 
Consequently, a further deterioration of livelihoods became inevitable and the communities became less resilient to both climatic and non-climatic vulnerabilities as confirmed by other studies $[10,83,84]$.

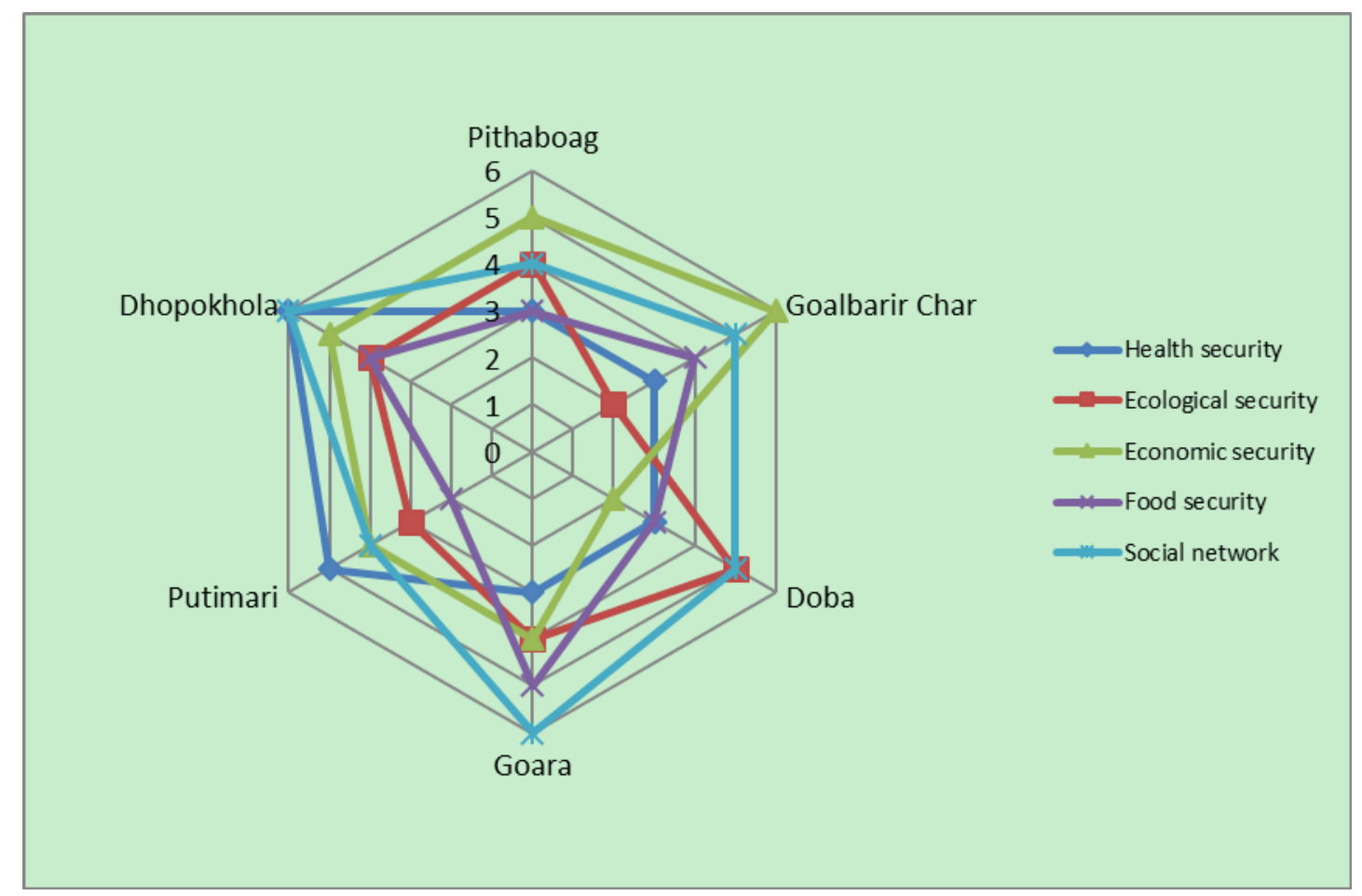

Figure 4. Third order impacts on livelihood assets (Source: reproduced from own survey data 2009, 2011).

This paper has significant relevance because its findings may help to inform the formulation of future climate change impacts adaptation policies in Bangladesh. In recent years, the country has prepared several key strategic adaptation documents including the Bangladesh Climate Change Strategy and Action Plan (BCCSAP) in 2009 and the 2005 National Adaptation Programme of Action (NAPA) for fighting against climate change vulnerabilities. However, these documents offer very dispersed and insignificant contributions to adaptive capacity and resilience building for local communities. For example, NAPA is a highly project-oriented document that mainly shows priority areas of concern and recommended projects which basically lack the comprehensiveness required to strengthen adaptive capacity at the community level [85,86]. BCCSAP is more of a strategic document. It identified several immediate, mid-term, and long-term actions under six major themes-social protection, disaster management, infrastructure development, knowledge building, mitigation, and capacity building $[87,88]$.

Some of the critical issues that were overlooked in previous climate change adaptation policies such as social protection, food security, agricultural diversity, and livelihoods on different time horizons [88] constituted the focus of the present paper. It is therefore a point of departure towards a more inclusive climate change impacts adaptation approach that addresses the untouched issues of complex interconnectedness of impacts and vulnerability. The characterization of climate change impacts allows policy-makers to diagnose the vulnerability more critically in order to undertake anticipatory adaptation measures in a more open, democratic and participatory manner. However, adaptation is very context-specific and its implementation depends on micro, social, physical, and environmental 
factors [89-91]. Therefore, future climate change impacts adaptation policies need to be flexible to embrace local socio-ecological dynamics as well as climate change uncertainties [92,93].

\section{Conclusions and Future Directions}

The paper found that the vulnerability profile of the surveyed communities is a combination of their physical exposure to climatic events, their fragile economic conditions; the depleting resource base, the inability of formal institutions as well as the external pressures (such as shrimp farmers from outside the areas). This paper has found that first order impacts are immediately effecting mainly on affecting the physical and infrastructural asset bases of the community. In the study area, low socio-economic profiles led to slow recovery processes from the first order impacts and due to intensifying climatic events the residual impacts are increasing. Changes in land use and production patterns are noticeable as second order impacts. Consequently, any future disaster, albeit smaller in magnitude, dismantled the whole recovery processes and lead to further orders of impacts which are characterized by general societal and household failure to cope and adapt to the impacts.

The findings of this paper have greater implications for devising climate change impacts adaptation policies as well as managing and mitigating the impacts and reducing vulnerabilities of local communities. It is important to focus on the key factors of vulnerability such as exposure to hazards or stressors, susceptibility (or fragility), societal response capacities, and lack of resilience. In order to make adaptation to climate change impacts effective, it is also important to consider the complexities of the impacts and the different orders of vulnerability. Therefore, the formulation of future adaptation policies should consider the non-linear, cumulative, and multi-order nature of climate change and the vulnerability of communities. In conclusion, the authors recommend the following adaptation measures for the consideration of policy-makers and climate change adaptation actors:

- Provision of access to health services, especially for the poor.

- Provision of financial support to smallholder farmers during the cropping season and long-term support after natural disasters. The financial support should be carefully designed so that the farmers will not be heavily indebted.

- Improving access to and diversifying livelihood sources/assets.

- Providing local communities with good physical infrastructure such as roads and access to markets.

- Excavate and re-excavate canals, rivers, and ponds to protect agricultural lands that are being invaded by saline water during high tide.

- Build protective walls to prevent saline water from entering ponds when cyclones strike.

- Develop and empower community-based organizations to provide effective social network services during and after natural disaster disasters. In cooperation with local institutions such as Union Councils, local communities should work as brokers of social networking through the provision of knowledge, information, and advisory services.

Despite the fact that the emphasis of this paper is to characterize impacts of climate change rather than proposing adaptation measures, the measures proposed herein can potentially improve the ability of the local communities to improve their adaptive capacities and resilience to mitigate the impacts, to 
recover therefrom, and to prevent exposure to future climate change events. Further research work is necessary to identify community and ecosystem specific adaptation and resilience measures.

\section{Acknowledgments}

The authors are grateful to two anonymous reviewers for their constructive comments and suggestions. Nazmul Huq acknowledges VLIR-UOS of Belgium for supporting the study. The authors are also grateful to the communities of the six studied villages for participating in the PRA session and approved their opinion to be published. Animesh Kumar Gain is supported by Alexander von Humboldt Foundation whose support is gratefully acknowledged.

\section{Author Contributions}

Conceptualization, methodology and data analysis were done by Nazmul Huq with the assistance of Jean Huge and Emmanuel Boon. Nazmul Huq, Jean Huge, Emmanuel Boon and Animesh Kumar Gain equally contributed in the writing of the paper including interpretation and editing.

\section{Conflicts of Interest}

The authors declare no conflict of interest.

\section{References}

1. Huq, N.; Hugé, J. Workers' rights in climate change policies: The case of adaptation programmes in Small Island Developing States. Int. J. Labour Res. 2010, 2, 163-185.

2. Intergovernmental Panel on Climate Change (IPCC). Managing the Risks of Extreme Events and Disasters to Advance Climate Change Adaptation. A Special Report of Working Groups I and II of the Intergovernmental Panel on Climate Change; Field, C.B., Barros, V., Stocker, T.F., Qin, D., Dokken, D.J., Ebi, K.L., Mastrandrea, M.D., Mach, K.J., Plattner, G.-K., Allen, S.K., et al., Eds.; Cambridge University Press: Cambridge, UK; New York, NY, USA, 2012.

3. Intergovernmental Panel on Climate Change (IPCC). Summary for policymakers. In Climate Change 2014: Impacts, Adaptation, and Vulnerability. Part A: Global and Sectoral Aspects. Contribution of Working Group II to the Fifth Assessment Report of the Intergovernmental Panel on Climate Change; Field, C.B., Barros, V.R., Dokken, D.J., Mach, K.J., Mastrandrea, M.D., Bilir, T.E., Chatterjee, M., Ebi, K.L., Estrada, Y.O., Genova, R.C., et al., Eds.; Cambridge University Press: Cambridge, UK; New York, NY, USA, 2014; pp. 1-32.

4. Xu, J.; Grumbine, R.E.; Shrestha, A.; Eriksson, M.; Yang, X.; Wang, Y.; Wilkes, A. The melting Himalayas: Cascading effects of climate change on water, biodiversity, and livelihoods. Conserv. Biol. 2009, 23, 520-530.

5. Adger, W.N.; Hughes, T.P.; Folke, C.; Carpenter, S.R.; Rockström, J. Social-ecological resilience to coastal disasters. Science 2005, 309, 1036-1039.

6. CERD EM-DAT: International Disaster Database. Available online: http://www.emdat.be/ (accessed on 20 March 2015). 
7. Gain, A.; Apel, H.; Renaud, F.; Giupponi, C. Thresholds of hydrologic flow regime of a river and investigation of climate change impact-The case of the Lower Brahmaputra river Basin. Clim. Chang. 2013, 120, 463-475.

8. Aleksandrova, M.; Gain, A.; Giupponi, C. Assessing agricultural systems vulnerability to climate change to inform adaptation planning: An application in Khorezm, Uzbekistan. Mitig. Adapt. Strateg. Glob. Chang. 2015. doi:10.1007/s11027-015-9655-y.

9. Jongman, B.; Hochrainer-Stigler, S.; Feyen, L.; Aerts, J.C.J.H.; Mechler, R.; Botzen, W.J.W.; Bouwer, L.M.; Pflug, G.; Rojas, R.; Ward, P.J. Increasing stress on disaster-risk finance due to large floods. Nat. Clim. Chang. 2014, 4, 264-268.

10. Neil Adger, W.; Arnell, N.W.; Tompkins, E.L. Successful adaptation to climate change across scales. Glob. Environ. Chang. 2005, 15, 77-86.

11. Turner, B.L.; Kasperson, R.E.; Matson, P.A.; McCarthy, J.J.; Corell, R.W.; Christensen, L.; Eckley, N.; Kasperson, J.X.; Luers, A.; Martello, M.L.; et al. A framework for vulnerability analysis in sustainability science. Proc. Natl. Acad. Sci. USA 2003, 100, 8074-8079.

12. Shamsuddoha, M.; Islam, M.; Haque, M.A.; Rahman, M.F.; Roberts, E.; Hasemann, A.; Roddick, S. Local Perspective on Loss and Damage in the Context of Extreme Events: Insights from Cyclone-Affected Communities in Coastal Bangladesh; Center for Participatory Research and Development (CRPD): Dhaka, Bangladesh, 2013.

13. Gain, A.K.; Giupponi, C.; Renaud, F.G. Climate Change Adaptation and Vulnerability Assessment of Water Resources Systems in Developing Countries: A Generalized Framework and a Feasibility Study in Bangladesh. Water 2012, 4, 345-366.

14. Hossain, Z.; Huq, N. Institutions Matter for Urban Resilience: The Institutional Challenges in Mainstreaming Climate Smart Disaster Risk Management in Bangladesh. In Climate Change and Disaster Risk Management; Leal Filho, W., Ed.; Climate Change Management; Springer: Berlin, Germany; Heidelberg, Germany, 2013; pp. 169-191.

15. Huq, N.; Hossain, Z.; Hasan, R.; Azad, A.M. "Climate Proofing” Water Resources Development Policy: The Evidence from Bangladesh. In Climate Change and the Sustainable Use of Water Resources; Leal Filho, W., Ed.; Climate Change Management; Springer: Berlin, Germany; Heidelberg, Germany, 2012; pp. 389-400.

16. Auerbach, L.W.; Goodbred, S.L., Jr.; Mondal, D.R.; Wilson, C.A.; Ahmed, K.R.; Roy, K.; Steckler, M.S.; Small, C.; Gilligan, J.M.; Ackerly, B.A. Flood risk of natural and embanked landscapes on the Ganges-Brahmaputra tidal delta plain. Nat. Clim. Chang. 2015, 5, 153-157.

17. Huq, N.; Hugé, J. "Greening” Integrated Water Resources Management Policies for Tackling Climate Change Impacts: A Call for Sustainable Development. In Climate Change and the Sustainable Use of Water Resources SE-11; Leal Filho, W., Ed.; Springer: Berlin and Heidelberg, Germany, 2012; pp. 173-183.

18. Karim, M.R.; Ishikawa, M.; Ikeda, M.; Islam, T. Climate change model predicts 33\% rice yield decrease in 2100 in Bangladesh. Agron. Sustain. Dev. 2012, 32, 821-830.

19. Karim, M.F.; Mimura, N. Impacts of climate change and sea-level rise on cyclonic storm surge floods in Bangladesh. Glob. Environ. Chang. 2008, 18, 490-500. 
20. Burton, I.; Malone, E.L.; Huq, S. Adaptation Policy Frameworks for Climate Change: Developing Strategies, Policies and Measures; Lim, B., Spanger-Siegfried, E., Eds.; Cambridge University Press: Cambridge, UK, 2004.

21. Huq, S.; Yamin, F.; Rahman, A.; Chatterjee, A.; Yang, X.; Wade, S.G.; Orindi, V.; Chigwada, J. Linking climate adaptation and development: A synthesis of six case studies from Asia and Africa. IDS Bull. 2005, 36, 117-122.

22. Brammer, H. After the Bangladesh Flood Action Plan: Looking to the future. Environ. Hazards 2010, 9, 118-130.

23. Brammer, H. Bangladesh's dynamic coastal regions and sea-level rise. Clim. Risk Manag. 2014, 1, 51-62.

24. Mallick, B.; Rahaman, K.R.; Vogt, J. Coastal livelihood and physical infrastructure in Bangladesh after cyclone Aila. Mitig. Adapt. Strateg. Glob. Chang. 2011, 16, 629-648.

25. Alam, M.J.B.; Ahmed, F. Indian Ocean Tropical Cyclones and Climate Change; Charabi, Y., Ed.; Springer: Dordrecht, The Netherlands, 2010.

26. Rabbani, M.D.G.; Rahman, A.A.; Mainuddin, K. Women's vulnerability to water-related hazards: Comparing three areas affected by climate change in Bangladesh. Waterlines 2009, 28, 235-249.

27. Ahmed, F.; Al-Amin, A.Q.; Alam, G.M. Climate change issues: Challenges for natural resource management in bangladesh-A way forward. Int. J. Glob. Warm. 2012, 4, 68-80.

28. Thomas, T.S.; Mainuddin, K.; Chiang, C.; Rahman, A.; Haque, A.; Islam, N.; Sun, Y.; Quasem, S. Agriculture and Adaptation in Bangladesh Current and Projected Impacts of Climate Change; The International Food Policy Research Institute (IFPRI): Washington, DC., USA, 2013.

29. Sarwar, M.G.; Woodroffe, C.D. Rates of shoreline change along the coast of Bangladesh. J. Coast. Conserv. 2013, 17, 1-12.

30. Penning-Rowsell, E.C.; Sultana, P.; Thompson, P.M. The "last resort"? Population movement in response to climate-related hazards in Bangladesh. Environ. Sci. Policy 2012, 27, 1-16.

31. Ahmed, F.; Mahabubul, G.; Al-Amin, A.Q.; Bin Hassan, C.H. The Impact of Climate Changes on Livestock Sector: Challenging Experience from Bangladesh. Asian J. Anim. Vet. Adv. 2013, 8, 29-40.

32. Mallick, B.J.; Witte, S.M.; Sarkar, R.; Mahboob, A.S.; Vogt, J. Local Adaptation Strategies of a Coastal Community during Cyclone Sidr and their Vulnerability Analysis for Sustainable Disaster Mitigation Planning in Bangladesh. J. Bangladesh Inst. Plan. 2012, 2, 158-168.

33. Alam, E.; Collins, A.E. Cyclone disaster vulnerability and response experiences in coastal Bangladesh. Disasters 2010, 34, 931-954.

34. Agrawala, S.; Ota, T.; Ahmed, A.U.; Smith, J.; van Aalst, M. Development and Climate Change in Bangladesh: Focus on Coastal Flooding and the Sundarbans; Organisation for Economic Co-operation and Development: Paris, France, 2003.

35. Rimi, R.H.; Farzana, S.; Sheikh, S.; Abedin, Z.; Bhowmick, A.C. Climate Change Impacts on Shrimp Production at the South-West Coastal Region of Bangladesh. World Environ. 2013, 3, 116-125.

36. World Bank. Bangladesh Climate Change and Sustainable Development; The World Bank: Dhaka, Bangladesh, 2000. 
37. Mirza, M.M.Q. Climate change, flooding in South Asia and implications. Reg. Environ. Chang. 2011, 11, 95-107.

38. Haque, A.N.; Dodman, D.; Hossain, M.M. Individual, communal and institutional responses to climate change by low-income households in Khulna, Bangladesh. Environ. Urban. 2014. doi:10.1177/0956247813518681.

39. Rahman, A.; Miah, G. Causes of coastal ecosystem degradation in Bangladesh. In Proceedings of the 10th Global Congress on ICM: Lessons Learned to Address New Challenges, EMECS 2013-MEDCOAST 2013 Joint Conference, Marmaris, Turkey, 30 October-3 November 2013; Middle East Technical University: Ankara, Turkey, 2013; Volume 2, pp. 853-862.

40. Adger, W.N. Vulnerability. Glob. Environ. Chang. 2006, 16, 268-281.

41. Birkmann, J. Measuring vulnerability to promote disaster-resilient societies: Conceptual frameworks and definitions. In Measuring Vulnerability to Natural Hazards: Towards Disaster Resilient Societies; Birkmann, J., Ed.; UNU Press: Tokyo, Japan; New York, NY, USA; Paris, France, 2006; Volume 1, pp. 9-54.

42. O’Brien, K.; Eriksen, S.; Nygaard, L.P.; Schjolden, A. Why different interpretations of vulnerability matter in climate change discourses. Clim. Policy 2007, 7, 73-88.

43. Morton, J.F. The impact of climate change on smallholder and subsistence agriculture. Proc. Natl. Acad. Sci. USA 2007, 104, 19680-19685.

44. Pavlickova, K.; Vyskupova, M. A method proposal for cumulative environmental impact assessment based on the landscape vulnerability evaluation. Environ. Impact Assess. Rev. 2015, 50, 74-84.

45. Ruane, A.C.; Major, D.C.; Yu, W.H.; Alam, M.; Hussain, S.G.; Khan, A.S.; Hassan, A.; Al Hossain, B.M.T.; Goldberg, R.; Horton, R.M.; et al. Multi-factor impact analysis of agricultural production in Bangladesh with climate change. Glob. Environ. Chang. 2013, 23, 338-350.

46. Parry, M.; Canziani, O.; Palutikof, J.; Adger, N.; Aggarwal, P.; Agrawala, S.; Alcamo, J.; Allali, A.; Anisimov, O.; Arnell, N.; et al. Technical Summary. In Climate Change 2007: Impacts, Adaptation and Vulnerability. Contribution of Working Group II to the Fourth Assessment Report of the Intergovernmental Panel on Climate Change; Cambridge University Press: Cambridge, UK; New York, NY, USA, 2007.

47. World Resource Institute (WRI). Weathering the Storm: Options for Framing Adaptation; World Resources Institute: Washington, DC, USA, 2007.

48. Birkmann, J. Risk and vulnerability indicators at different scales: Applicability, usefulness and policy implications. Environ. Hazards 2007, 7, 20-31.

49. Birkmann, J.; Cardona, O.D.; Carreño, M.L.; Barbat, A.H.; Pelling, M.; Schneiderbauer, S.; Kienberger, S.; Keiler, M.; Alexander, D.; Zeil, P.; et al. Framing vulnerability, risk and societal responses: The MOVE framework. Nat. Hazards 2013, 67, 193-211.

50. Birkmann, J. First- and second-order adaptation to natural hazards and extreme events in the context of climate change. Nat. Hazards 2011, 58, 811-840.

51. Costa, L.; Kropp, J.P. Linking components of vulnerability in theoretic frameworks and case studies. Sustain. Sci. 2012, 8, 1-9.

52. Füssel, H.-M. Vulnerability: A generally applicable conceptual framework for climate change research. Glob. Environ. Chang. 2007, 17, 155-167. 
53. Füssel, H.-M.; Klein, R.J.T. Climate Change Vulnerability Assessments: An Evolution of Conceptual Thinking. Clim. Chang. 2006, 75, 301-329.

54. Gallopín, G.C. Linkages between vulnerability, resilience, and adaptive capacity. Glob. Environ. Chang. 2006, 16, 293-303.

55. Ellis, F. A Livelihoods Approach to Migration and Poverty Reduction; Overseas Development Group, University of East Anglia: Norwich, UK, 2003.

56. Scoones, I. Livelihoods perspectives and rural development. J. Peasant Stud. 2009, 36, 171-196.

57. Ford, J.D.; Smit, B. A Framework for Assessing the Vulnerability of Communities in the Canadian Arctic to Risks Associated with Climate Change. Arctic 2004, 57, 389-400.

58. Pearson, L.; Langridge, J.; Crimp, S.; Nelson, R. Climate Change Vulnerability Assessment; Review of Agricultural Productivity; CSIRO Climate Adaptation Flagship Working Paper; CSIRO: Dickson, ACT, Australia, 2008.

59. Scoones, I. Sustainable Rural Livelihods. A Framework for Analsyis; Institute of Development Studies: Sussex, UK, 1998.

60. Brien, K.O.; Ulsrud, K.; Eriksen, S.E.H.; Klein, R.J.T.; Næss, L.O.; O’Brien, K. Climate Change Adaptation and Poverty Reduction: Key Interactions and Critical Measures; University of Oslo: Oslo, Norway, 2007.

61. Department for International Development (DFID). Defining Disaster Resilience: A DFID Approach Paper Kenya: Camels Replacing Cattle; Department for International Development: London, UK, 2011.

62. Khatun, M. Climate Change and Migration in Bangladesh: Golden Bengal to Land of Disasters. Bangladesh e-J. Sociol. 2013, 10, 64-79.

63. Salauddin, M.; Ashikuzzaman, M. Nature and extent of population displacement due to climate change-triggered disasters in the south-western coastal region of Bangladesh. Manag. Environ. Qual. 2011, 22, 620-631.

64. Ali, A. Climate change impacts and adaptation assessment in Bangladesh. Clim. Res. 1999, 12, 109-116.

65. Adger, W.N.; Dessai, S.; Goulden, M.; Hulme, M.; Lorenzoni, I.; Nelson, D.R.; Naess, L.O.; Wolf, J.; Wreford, A. Are there social limits to adaptation to climate change? Clim. Chang. 2008, 93, 335-354.

66. Smit, B.; Skinner, M.W. Adaptation Options in Agriculture to Climate Change: A typology. Mitig. Adapt. Strateg. Glob. Chang. 2002, 7, 85-114.

67. Cannon, T. Reducing People's Vulnerability to Natural Hazards-Communities and Resilience; Research Paper; UNU-WIDER: Helsinki, Finland, 2008.

68. Moser, C.; Stein, A. Implementing Urban Participatory Climate Change Adaptation Appraisals: A Methodological Guideline. Environ. Urban. 2011, 23, 463-485.

69. Chambers, R. The Origins and Practice of Participatory Appraisal. World Dev. 1994, 22, 953-969.

70. Narayanasamy, N. Participatory Rural Appraisal: Principles, Methods and Application; SAGE Publications Pvt. Ltd.: New Delhi, India, 2009.

71. Hasan, M.; Roe, M. Participatory Planning and Environmental Management for Salinity Affected Coastal Regions of Bangladesh; Bangladesh Centre for Human Welfare and Sustainable Development: Khulna, Bangladesh, 2004. 
72. Webber, A.D.; Hill, C.M. Using participatory risk mapping (PRM) to identify and understand people's perceptions of crop loss to animals in Uganda. PLOS ONE 2014, 9, e102912.

73. McGranahan, G.; Balk, D.; Anderson, B. The rising tide: Assessing the risks of climate change and human settlements in low elevation coastal zones. Environ. Urban. 2007, 19, 17-37.

74. Hofer, T.; Messerli, B. Floods in Bangladesh: History, Dynamics and Rethinking the Role of the Himalayas; United Nations University: Tokyo, Japan, 2006.

75. IPCC. Climate Change 2007: Synthesis Report-An Assessment of the Intergovernmental Panel on Climate Change; Cambridge University Press: Cambridge, UK and New York, NY, USA, 2007.

76. Rabbani, G.; Rahman, A.; Mainuddin, K. Salinity-induced loss and damage to farming households in coastal Bangladesh. Int. J. Glob. Warm. 2013, 5, 400-415.

77. Islam, M.M.; Sallu, S.; Hubacek, K.; Paavola, J. Vulnerability of fishery-based livelihoods to the impacts of climate variability and change: Insights from coastal Bangladesh. Reg. Environ. Chang. 2013, 14, 281-294.

78. Rabbani, G.; Rahman, S.; Faulkner, L. Impacts of Climatic Hazards on the Small Wetland Ecosystems (ponds): Evidence from Some Selected Areas of Coastal Bangladesh. Sustainability 2013, 5, 1510-1521.

79. Vineis, P.; Chan, Q.; Khan, A. Climate change impacts on water salinity and health. J. Epidemiol. Glob. Health 2011, 1, 5-10.

80. Ali, A.M.S. Rice to shrimp: Land use/land cover changes and soil degradation in Southwestern Bangladesh. Land Use Policy 2006, 23, 421-435.

81. Haque, M.A.; Budi, A.; Azam Malik, A.; Suzanne Yamamoto, S.; Louis, V.R.; Sauerborn, R. Health coping strategies of the people vulnerable to climate change in a resource-poor rural setting in Bangladesh. BMC Public Health 2013, 13, 565.

82. Vineis, P.; Khan, A. Climate change-induced salinity threatens health. Science 2012, 338, 1028-1029.

83. Adger, W.N. Social and ecological resilience: Are they related? Prog. Hum. Geogr. 2000, 24, 347-364.

84. Hanazaki, N.; Berkes, F.; Seixas, C.S.; Peroni, N. Livelihood Diversity, Food Security and Resilience among the Caiçara of Coastal Brazil. Hum. Ecol. 2012, 41, 153-164.

85. Ahammad, R. Constraints of pro-poor climate change adaptation in chittagong city. Environ. Urban. 2011, 23, 503-515.

86. Prowse, M.; Grist, N.; Sourang, C. Closing the Gap between Climate Adaptation and Poverty Reduction Frameworks; Oversease Development Institute: London, UK, 2009.

87. Alam, K.; Shamsuddoha, M.; Tanner, T.; Sultana, M.; Huq, M.J.; Kabir, S.S. The Political Economy of Climate Resilient Development Planning in Bangladesh. IDS Bull. 2011, 42, 52-61.

88. MOEF. Bangladesh Climate Change Strategy and and Action Plan; Ministry of Environment and Forest: Dhaka, Bangladesh, 2009.

89. Pahl-Wostl, C. A conceptual framework for analysing adaptive capacity and multi-level learning processes in resource governance regimes. Glob. Environ. Chang. 2009, 19, 354-365.

90. Gupta, J.; Termeer, C.; Klostermann, J.; Meijerink, S.; van den Brink, M.; Jong, P.; Nooteboom, S.; Bergsma, E. The Adaptive Capacity Wheel: A method to assess the inherent characteristics of institutions to enable the adaptive capacity of society. Environ. Sci. Policy 2010, 13, 459-471. 
91. Huntjens, P.; Lebel, L.; Pahl-Wostl, C.; Camkin, J.; Schulze, R.; Kranz, N. Institutional design propositions for the governance of adaptation to climate change in the water sector. Glob. Environ. Chang. 2012, 22, 67-81.

92. Larson, A.M.; Soto, F. Decentralization of Natural Resource Governance Regimes. Annu. Rev. Environ. Resour. 2008, 33, 213-239.

93. Travers, A.; Elrick, C.; Kay, R.; Vestergaard, O. Ecosystem-Based Adaptation Guidance: Moving from Principles to Practice; United Nations Environment Programme: Nairobi, Kenya, 2012.

(C) 2015 by the authors; licensee MDPI, Basel, Switzerland. This article is an open access article distributed under the terms and conditions of the Creative Commons Attribution license (http://creativecommons.org/licenses/by/4.0/). 